\title{
NUTRIENT LOADING ON THE EASTERN GULF OF FINLAND (BALTIC SEA) FROM THE RUSSIAN CATCHMENT AREA
}

\author{
SERGEY KONDRATYEV ${ }^{1)}$, NATHANIEL TRUMBULL ${ }^{2)}$ \\ ${ }^{1)}$ Institute of Limnology of the Russian Academy of Sciences, St. Petersburg, Russian Federation; Mailto:kondratyev@limno.org.ru \\ ${ }^{2)}$ Department of Geography, University of Connecticut, Groton, CT, USA; trumbull@uconn.edu
}

The identification and examination of sources of external loading are important pressure indicators for studying the nutrient balance and eutrophication of water bodies. Focusing on the eastern Gulf of Finland, this paper investigates and decomposes the sources of phosphorus, a limiting factor of eutrophication of the Gulf and its accompanying Neva Bay, and of nitrogen as pressure indicators. The eastern Gulf of Finland's catchment basin represents Europe's largest freshwater basin. Both point and non-point sources of pollution, as well as their current and possible withdrawals from the watershed's nutrient loading, are considered. The investigation identifies poultry plants and animal husbandry enterprises in the coastal watershed as critical contributing sources to eutrophication in the eastern Gulf of Finland. Analyses based on such pressure indicators can help to contribute directly to future policy-making as concerns environmental protection measures and water resources planning in the eastern Gulf of Finland and other regions.

KEY WORDS: External Loading, Phosphorus, Nitrogen, Point and Non-point Sources, Wastewater Treatment Plants, Baltic Sea Action Plan.

Sergej Kondratiev, Nathaniel Trumbull: ZÁŤAŽ VÝCHODNEJ ČASTI FÍNSKEHO ZÁLIVU (BALTICKÉ MORE) ŽIVINAMI Z RUSKEJ ČASTI POVODIA. J. Hydrol. Hydromech., 60, 2012, 3; 11 lit., 5 obr., 2 tab.

Identifikácia zdrojov externej zát’aže živinami je významným indikátorom pre štúdium bilancie živín a eutrofizácie vôd. Tento príspevok prezentuje výsledky výskumu zdrojov fosforu a sodíka východnej časti Fínskeho zálivu a delty rieky Nevy, ako limitujúcich faktorov eutrofizácie. Povodie východnej časti Fínskeho zálivu je najväčším európskym zdrojom sladkej vody. V analýze sú uvažované bodové a plošné zdroje znečistenia a tiež súčasné, ale aj možné odbery vody a znečist'ujúcich látok z povodia. Výskumom sa podarilo identifikovat' hydinárske farmy a vel'kochovy zvierat v pobrežnej zóne povodia ako kritické vzhl'adom na eutrofizáciu východnej časti Fínskeho zálivu. Výsledky analýzy môžu priamo prispiet' $\mathrm{k}$ tvorbe legislatívy týkajúcej sa ochrany životného prostredia a plánovania využitia zdrojov vody vo východnej časti Fínskeho zálivu, ale aj v iných regiónoch.

KLÚČOVÉ SLOVÁ: vonkajšia zát'až živinami, fosfor, sodík, bodové a nebodové zdroje, čistiarne odpadových vôd, Akčný plán Baltického mora.

\section{Introduction}

Decomposing the sources of external nutrient loading can serve to identify important driving forces in the study of the nutrient balance of water bodies. External nutrient loading is a continuously occurring factor that determines the quality of water in the water body by influencing the chemical content of sedimentation and hydrobiological processes. An understanding of external loading was introduced by Sawyer (1947) within the framework of a study of the dependence of trophic condition of water from the phosphorus and nitrogen introduced into it. The main source of natural loading is the release of chemical substances from natural landscapes (forest, swamp, meadows of natural origin and other) under the influence of rain and melted snow (OECD, 1982; Vollenweider, 1968). Anthropogenic sources consist of the release of wastewaters from industrial, municipal, and agricultural enterprises, as well as of diluted and suspended contaminants from arable lands and pastures, and fertilized and abandoned areas. The east- 
ern Gulf of Finland is one of the most eutrophic of the Baltic Sea's water bodies.

The Russian Federation from 1997-2003 contributed more than three-fourths of the phosphorus and more than two-thirds of the nitrogen that entered the Gulf of Finland from its catchment basin (Helsinki Commission, 2009). In November 2007 the Helsinki Commission (HELCOM) approved the Baltic Sea Action Plan (BSAP), which serves as a long-term strategy for the improvement of the Baltic Sea (Helsinki Commission, 2007). One of the most important areas of the BSAP is the creation of mitigation efforts for decreasing the flow of Total Phosphorus $\left(\mathrm{P}_{t o t}\right)$ and Total Nitrogen $\left(\mathrm{N}_{t o t}\right)$ into the ecosystem. BSAP in future plans to require payment for excessive outflow of nutrient loading into the Baltic Sea from each country. According to BSAP, the maximum recommended nutrient loadings are 4860 tons $\mathrm{P}_{t o t}$ and 106,680 tons $\mathrm{N}_{t o t}$ for the Gulf of Finland. The requirements for decreasing the loading on the Baltic Sea are calculated as a result of calculations conducted by the models MARE NEST, managed in Sweden.

Based on the principles of eutrophication of water bodies, it does not appear entirely convincing that the stated goal of the authors of the BSAP to achieve a "Baltic Sea unaffected by eutrophication" (Helsinki Commission, 2007) could be realized solely through reduction of the loadings of $\mathrm{P}_{t o t}$ and $\mathrm{N}_{t o t}$. Eutrophication takes place in all water bodies, and its intensity does not always depend only on the introduction of total forms of nutrients. Nonetheless, the countries of the Baltic Sea region at the current time should aim to implement BSAP recommendations. One hopes that in future the authors of such international agreements can be more attentive to the viewpoints of scientists.

The purpose of this paper is an evaluation and decomposing of the sources of external loading of $\mathrm{P}_{t o t}$ and $\mathrm{N}_{t o t}$ in the eastern Gulf of Finland of the Baltic Sea. The study focuses on the Russian territory of the watershed and seeks to identify as pressure indicators the contributions of the different sources of nutrient loading. In addition, an attempt is made to evaluate the possible and most realistic scenarios for a lowering of nutrient loading on the Gulf of Finland.

\section{Materials and methods}

It is possible to delineate four main sources of nutrient loading on the Gulf of Finland from Russian territory (Fig. 1): the flow of nutrients from
Lake Ladoga through the Neva River, the flow of nutrients from Lake Chudskoye/Peipsi and the Narva reservoir through the Narva River, nutrient loading from the coastal watershed of the eastern Gulf of Finland and the wastewater of the city of St. Petersburg.

In order to quantify the nutrient loading on Neva Bay and the Gulf of Finland from Russian territory, this study draws on the results of Russian state monitoring and statistical results, reports from the Water Purveyor Enterprise "Vodokanal SPb" concerning its wastewater treatment plants in St. Petersburg, and the results of previous studies of the impacts on water quality of Lake Ladoga on the Gulf of Finland (Helsinki Commission, 2009).

In order to identify the sources and calculate the amounts of nutrient loading from the coastal watershed of the eastern Gulf of Finland, a mathematical model was used (Kondratyev, 2007; Kondratyev et al., 2009). This model was designed to estimate annual nutrient input into water bodies. The model makes possible the calculation of the annual nutrient leaching in different landscape units with various types of soil and vegetation, land use and soil nutrient content. The model takes into account the contributions of point and non-point sources in the formation of loading on the watershed. The model permits the calculation of loading from both those types of sources while at the same time considers the effect of hydrological factors. Uptake with crops is another important calculated component of the nutrient balance of the studied catchment. The model can thus investigate the impact of agricultural activities and increased fertilizer use. Nutrient retention in surface waters is calculated depending on specific runoff and percentage of water area in the watershed. The dynamic model is run with a time step of one year. The modeling overall makes possible a quantitative analysis of the external loading into the eastern Gulf of Finland by means of decomposing the sources of that loading.

\section{Results and discussion}

The remainder of the Russian territory of the eastern Gulf of Finland basin is the watershed of Lake Ladoga (approx. 280,000 $\mathrm{km}^{2}$ ), including the watersheds of Lake Onega, Lake Il'men' and Lake Saimaa (Finland). About $20 \%$ of area is located in Finland, $1 \%$ in Belarus Republic. The main components of nutrient loading in Lake Ladoga, conducted for the period 1980-2005, are shown below in Fig. 2 (Kondratyev, 2007). The most significant 


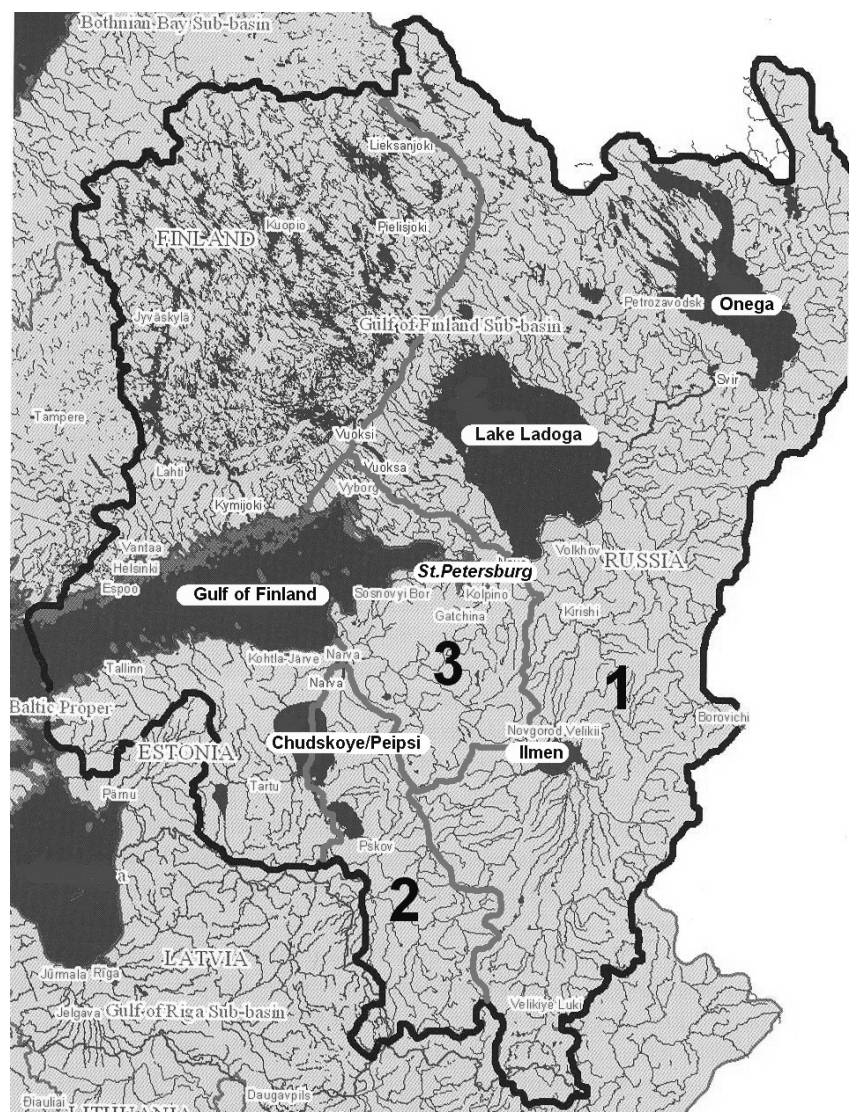

Fig. 1. Watersheds of the Gulf of Finland and its Russian territory: 1. Watershed of Lake Ladoga; 2. Watershed of Lake Chudskoye/Peipsi and Narva Reservoir; and 3. Coastal watershed of the eastern Gulf of Finland.

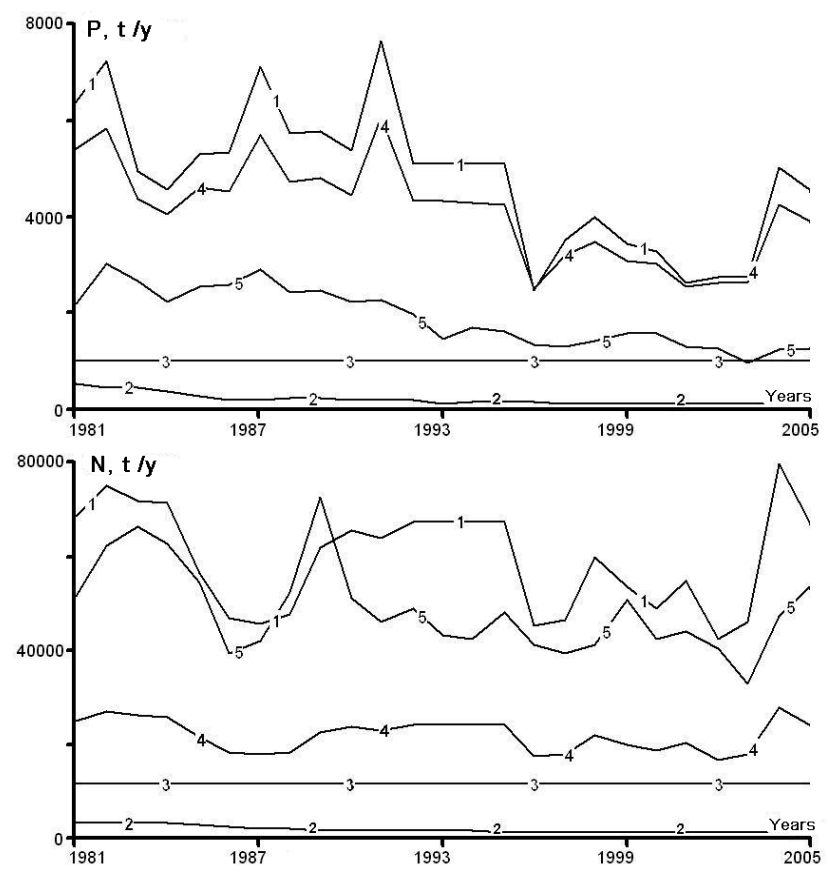

Fig. 2. The nutrient balance $\left(\mathrm{N}_{t o t}\right.$ and $\left.\mathrm{P}_{t o t}\right)$ of Lake Ladoga: 1 . release into the lake from the watershed; 2 . internal loading; 3 . atmospheric deposition; 4. retention in the lake; 5. release from Lake Ladoga into the Neva River (Kondratyev, 2007). components of the lake's nutrient balance are, on the one hand, the release of $\mathrm{N}_{t o t}$ and $\mathrm{P}_{t o t}$ from the rivers in the lake's watershed into Lake Ladoga, and on the other hand, the release of nutrients from Lake Ladoga into the Neva River. In 2007-2008, the release of nutrients from Lake Ladoga into the Neva River represented about 1,000 tons of $\mathrm{P}_{t o t}$ per year and 40,100 tons of $\mathrm{N}_{\text {tot }}$ per year (Golubev et al., 2009).

The Narva River and Lake Chudskoye/Peipsi watershed occupies about $56,800 \mathrm{~km}^{2}$ and is located within 4 countries: $63.3 \%$ of area - in Russian Federation, $30.2 \%$ - in Estonia, $5.9 \%$ - in Latvia and $0.6 \%$ - in the Belarus Republic. The outflow of nutrients from the Narva River, according to data from monitoring, are shown in Fig. 3. Taking into account the fact that $63.3 \%$ of the watershed is located on Russian territory, the nutrient loading on the Gulf of Finland from the Russian part of the watershed in 2007 can be calculated to be 297 tons per year for $\mathrm{P}_{t o t}$ and 6,570 tons per year for $\mathrm{N}_{t o t}$.

St. Petersburg (former Leningrad) is located on the islands of the delta of the Neva River, approximately 70 kilometers to the southwest of Lake La- 
doga. St. Petersburg, with a population of 4.6 million residents, is the largest urban population on the Gulf of Finland (Trumbull, 2007). The city's two largest wastewater treatment plants, which treat and release into Neva Bay, are the Northern Wastewater Plant and Central Wastewater Treatment Plant. Their capacities are $1,400,000 \mathrm{~m}^{3}$ and $6,000,000 \mathrm{~m}^{3}$ of wastewater per day. St. Petersburg's system of wastewater treatment has steadily been improved during the last decade. In 2004 the Southwest Wastewater Treatment Plant was opened and it reached wastewater processing capacity of 330,000 $\mathrm{m}^{3}$ in 2006. The trends of the release of $\mathrm{N}_{t o t}$ and $\mathrm{P}_{t o t}$ into Neva Bay from the city of St. Petersburg are presented in Fig. 4. In 2007 the nutrient loading of Neva Bay from St. Petersburg was about 1,200 tons of $\mathrm{P}_{t o t}$ per year and 11,000 tons of $\mathrm{N}_{t o t}$ per year (Vodokanal, 2008).
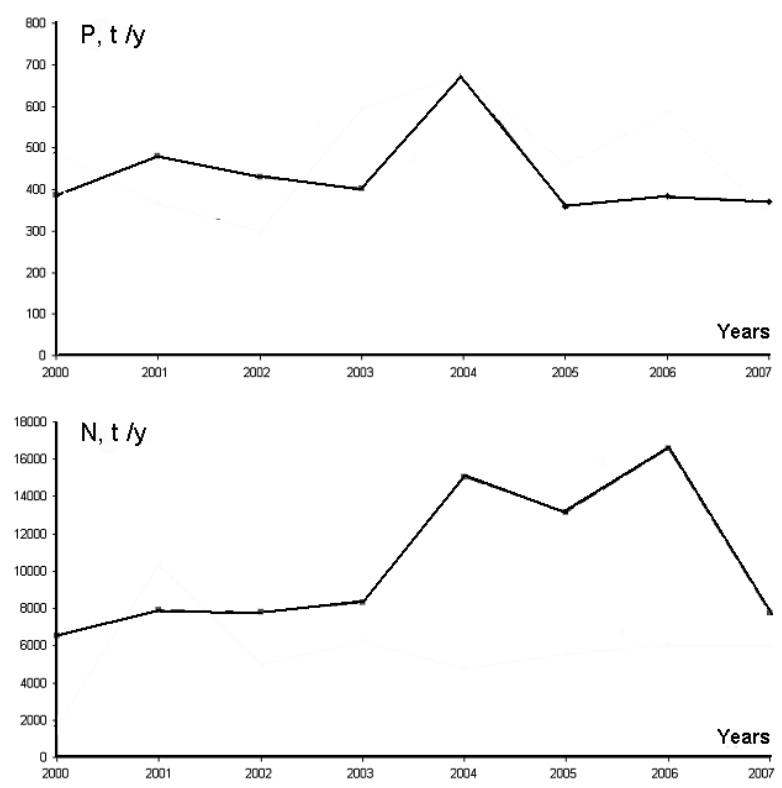

Fig. 3. The nutrient outflow $\left(\mathrm{N}_{t o t}\right.$ and $\left.\mathrm{P}_{t o t}\right)$ from the Narva reservoir through the Narva River.

The coastal watershed of the Gulf of Finland (approx. 28,000 $\mathrm{km}^{2}$ ), includes the watersheds of the Neva River (from its source to the mouth of Lake Ladoga, the Luga River, and small streams and of the northern and southern shore of the Gulf). In this area the results of monitoring are not sufficient for an assessment of the nutrient load on the Gulf. For this reason a model of nutrient loading developed by the Institute of Limnology of the Russian Academy of Sciences (RAS) was used for solving this problem (Kondratyev, 2007). In order to assess the annual characteristics of runoff, the hydrological model (Kondratyev, Mendel, 1996) developed by the Institute of Limnology RAS and the Institute of Hydrology SAS was employed. The results of the calculations of the main components of $\mathrm{P}_{t o t}$ loading on the coastal watershed of the Gulf of Finland from the period 1999-2007 are shown in Fig. 5a). The calculations are based on the assumption that all organic substances from farm activities contribute to the nutrient loading of the watershed. The calculated amount of nutrient loading from the coastal watershed is therefore the maximum possible. From the graph, one observes that the largest sources of loading, both for phosphorus as for nitrogen, are from poultry and animal husbandry enterprises. Differences in years in the amount of the loading on the watershed can be explained both by annual variability in production of the poultry plants and animal husbandry enterprises, as well as by varying precipitation levels over the observed period.

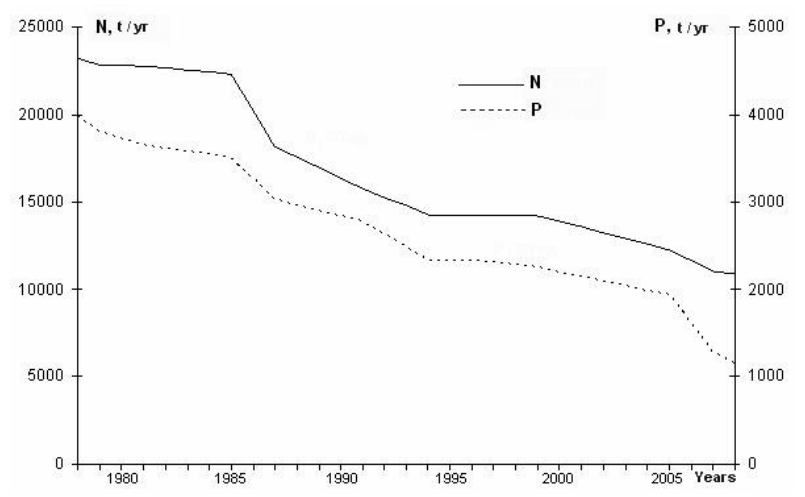

Fig. 4. Trends of total release of $\mathrm{N}_{t o t}$ and $\mathrm{P}_{t o t}$ (tons per year) into Neva Bay from the wastewater treatment plants of St. Petersburg.

As follows from the structure of the model (Kondratyev, 2007; Kondratyev et al., 2009), not all nutrients that fall on the surface of the watershed reach the Gulf of Finland. As a result of the removal of nutrients through harvesting and through the hydrographic net system, the loading on the Gulf of Finland is reduced by approximately $60 \%$ for both $\mathrm{P}_{t o t}$ and for $\mathrm{N}_{t o t}$. The trends during the year 1999 to 2007 in terms of $\mathrm{P}_{t o t}$ loading of the coastal watershed are also displayed in Fig. 5b). A similar calculation was conducted for $\mathrm{N}_{t o t}$. According to the results of modeling, the nutrient loading on the Gulf of Finland from the coastal watershed in 2007 was 2,736 tons of $\mathrm{P}_{\text {tot }}$ and 13,150 tons of $\mathrm{N}_{t o t}$. One observes the predominant role of poultry and animal husbandry enterprises in $\mathrm{P}_{t o t}$ loading of the coastal 
watershed. The natural component of loading from leaching of soils in the watershed is approximately $10 \%$ for $\mathrm{P}_{t o t}$ and $25 \%$ for $\mathrm{N}_{t o t}$.

A further decomposing of the values of nutrient loading on the Gulf of Finland from its principal components (from Lake Ladoga, from Narva reservoirs, from the coastal watershed and from St. Petersburg) reveals the following total nutrient loading amounts from Russian territory into the eastern Gulf of Finland: 5,233 tons per year for $\mathrm{P}_{t o t}$ and 70,820 tons per year for $\mathrm{N}_{\text {tot }}$ (Tab. 1). In comparing these calculated figures with the Baltic Sea Action Plan's recommendations for the entire Gulf of Finland (4,860 tons per year of $\mathrm{P}_{t o t}$ and 106,680 tons per year of $\mathrm{N}_{t o t}$, Helsinki Commission, 2007), the excessive level of the present-day loading of phosphorus from the Russian watershed of the eastern Gulf of Finland can be easily discerned and paths for lowering of the loading can be identified.

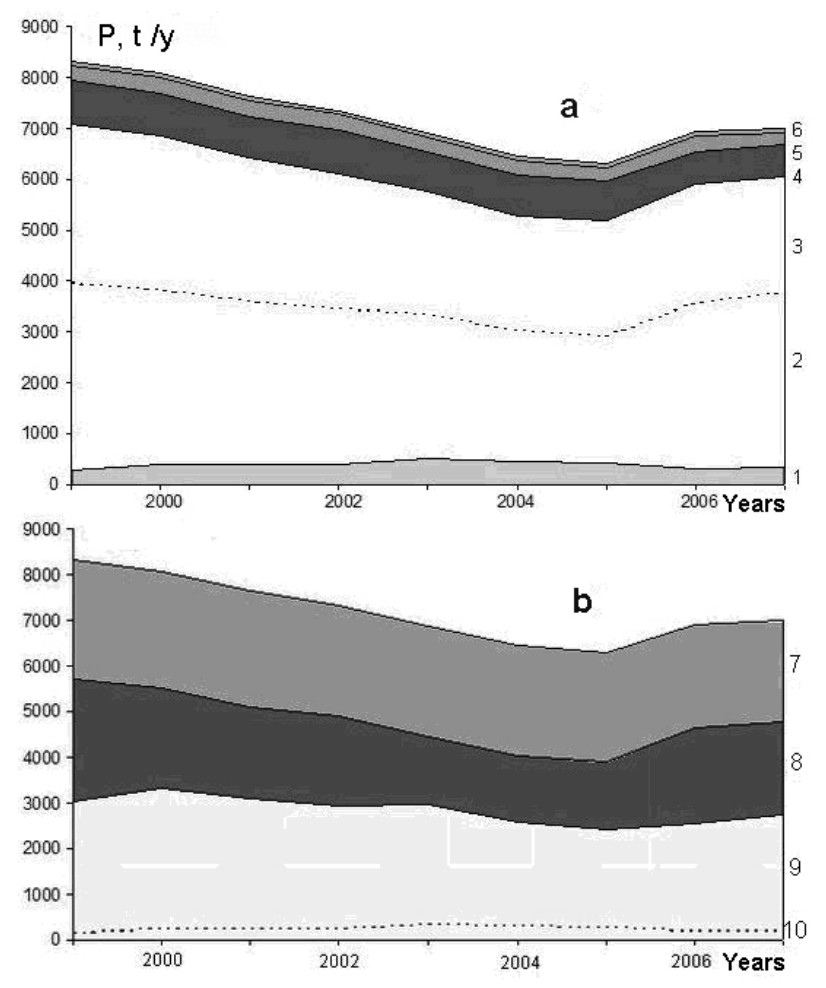

Fig. 5. Decomposing the sources of $\mathrm{P}_{\text {tot }}$ loading on the coastal watershed a) and on the eastern Gulf of Finland: a - (1) natural leaching from soils; (2) poultry enterprises; (3) animal husbandry enterprises; (4) mineral fertilizers; (5) point sources; (6) and atmospheric deposition; b) - (7) removal through harvesting; (8) retention by the watershed and hydrographic system; (9) anthropogenic sources (including poultry and animal husbandry enterprises); and (10) natural loading.

A comprehensive study of the nutrient balance of the Gulf of Finland at large may be completed only after the inclusion of similar data from Finland and Estonia, whose territories occupy approximately $35 \%$ of the area of the watershed of the Gulf of Finland. However it is readily apparent that opportunities for lowering the nutrient loading from the Russian territory of the eastern Gulf of Finland's coastal watershed must already now be actively identified and pursued by policy-makers.

It should be noted that almost $90 \%$ of the area of the watershed of the Russian part of the Gulf of Finland are watersheds of the largest European lakes. Those large water bodies (Lakes Saimaa, Ladoga, Onega, Ilmen and Chudskoe/Peipsi) serve as a partial geo-chemical barrier to the migration of nutrients from the upper watershed and out to the Gulf of Finland. Tab. 2 shows the calculated values of retention of $\mathrm{P}_{t o t}$ in these upper water bodies, which range from 0.53 to 0.76 . (Kondratyev, 2007) Consequently, the impact of any $\mathrm{P}_{t o t}$ reduction efforts associated with the change in loading in the upper watersheds would have a minimal impact on the nutrient loading of the eastern Gulf of Finland.

The wastewater treatment plants of St. Petersburg and the eastern Gulf of Finland's coastal watershed (Watershed 3 in Fig. 1), loading directly into the Neva River and Neva Bay, are the subject of special attention in this study.

The Baltic Sea Action Plan recommends lowering the concentration of $\mathrm{P}_{t o t}$ at the outlets of all wastewater treatment plants of the Baltic Sea watershed to $0.5 \mathrm{mg} \mathrm{l}^{-1}$. In this investigation, calculations were made for the loading of $\mathrm{P}_{t o t}$ in the eastern part of the Gulf of Finland as a result of the wastewater treatment plants of the Water Purveyor Enterprise "Vodokanal $\mathrm{SPb}$ " under conditions of $100 \%$ treatment of all city wastewater and of concentration amounts at the outlet of the wastewater treatment plants of $1.0,0.8$ and $0.5 \mathrm{mg} \mathrm{l}^{-1}$. The calculated results are, correspondingly, 1110, 910, and 610 tons $\mathrm{P}_{\text {tot }}$ per year. If the current level of loading of $\mathrm{P}_{t o t}$ from St. Petersburg (see Tab. 1) approximately corresponds to the calculated loading at a concentration of $1.0 \mathrm{mg} \mathrm{l}^{-1}$ of treated wastewater, then with an improvement in the level of wastewater treatment to $0.5 \mathrm{mg} \mathrm{l}^{-1}$, it is possible to expect a decrease in phosphorus loading of approximately 500 tons per year.

A more significant lowering of nutrient loading from non-point sources could be achieved in the coastal watershed of the eastern Gulf of Finland. As may be seen from the results of the modeling (Fig. 5 ), at present for the coastal watershed the nutrient removal through harvesting represents $35 \%$ for $\mathrm{P}_{t o t}$ 
and $56 \%$ for $\mathrm{N}_{t o t}$ of the amount of nutrients introduced to the surface of the watershed from mineral fertilizers and organic substances from farms and poultry plants. The current study employs simulation modeling under conditions of $80 \%$ and $100 \%$ capture of mineral and organic fertilizers from agricultural activities with their accompanying removal beyond the watershed through harvesting. The results of the calculations indicated that the resulting nutrient loading on the Gulf of Finland represents 1,295 tons $\mathrm{P}_{\text {tot }}$ per year and 10,290 tons $\mathrm{N}_{\text {tot }}$ per year under conditions of the removal of $80 \%$ mineral and organic fertilizers through harvesting, and represents 482 tons $\mathrm{P}_{\text {tot }}$ per year and 6,277 tons $\mathrm{N}_{\text {tot }}$ per year under conditions of the removal of $100 \%$ of mineral and organic fertilizers through harvesting. Such a significant lowering of nutrient loading (to 2,000 tons $\mathrm{P}_{t o t}$ per year and 5,000 tons $\mathrm{N}_{t o t}$ per year) would meet the Baltic Sea Action Plan's recommendations as concerns nutrient loading on the Gulf of Finland from the side of Russia. But such an "ideal" solution is highly unlikely today in the agricultural section of Northwest Russia. One can nevertheless conclude from the calculated results that an optimization of agriculture and the transfer of mineral and organic fertilizers through harvesting is an effective method of lowering the level of nutrient loading on the Gulf of Finland.

T a b l e 1. Nutrient loading on the Gulf of Finland from the Russian watershed in 2007.

\begin{tabular}{cccc}
\hline & Source of loading & $\mathrm{P}_{\text {tot }}$ [tons/year] & $\mathrm{N}_{\text {tot }}$ [tons/year] \\
\hline 1 & Lake Ladoga & 1,000 & 40,100 \\
2 & Lake Chudskoe/Peipsi and the Narva reservoir & 297 & 6,570 \\
3 & Coastal watershed & 2,736 & 13,150 \\
4 & St. Petersburg & 1,200 & 11,000 \\
& Total & 5,233 & 70,820 \\
\hline
\end{tabular}

T a b l e 2. Coefficients of $\mathrm{P}_{\text {tot }}$ retention in lakes located in the Gulf of Finland watershed (Kondratyev, 2007).

\begin{tabular}{lc}
\hline Name & Coefficient of $\mathrm{P}_{\text {tot }}$ retention \\
\hline Lake Saimaa (Finland) & 0.71 \\
Lake Onega & 0.76 \\
Lake Ladoga & 0.70 \\
Lake Ilmen & 0.53 \\
Lake Chudskoe/Peipsi & 0.56 \\
\hline
\end{tabular}

\section{Conclusions}

In accordance with the results of the completed calculations, the values of nutrient loading from the Russian territory into the eastern Gulf of Finland (from Lake Ladoga, from Narva reservoirs, from the coastal watershed and from St. Petersburg) are currently about 5,200 tons per year for $\mathrm{P}_{t o t}$ and 70,800 tons per year for $\mathrm{N}_{t o t}$. In comparing these calculated results with the Baltic Sea Action Plan's recommendations for the entire Gulf of Finland (4,860 tons per year of $\mathrm{P}_{t o t}$ and 106,680 tons per year of $\mathrm{N}_{\text {tot }}$, Helsinki Commission, 2007), it is critical to recommend, first and foremost, the lowering of phosphorus loading. A more precise and scientifically based investigation of the required lowering of nutrient loading on the Gulf of Finland from the territory of Russia can be completed after the inclusion in the modeling of data from Finland and Estonia, which occupy approximately $35 \%$ of the area of the watershed. However it is already critical now to identify a path for lowering the levels of loading from Russian territory.

This work demonstrates that the contribution of the wastewater treatment plants of St. Petersburg in lowering loading on the Gulf of Finland can represent approximately 500 tons of $\mathrm{P}_{t o t}$ per year, as a result of following the recommendations of the BSAP (Helsinki Commission, 2007) to lower the concentration of $\mathrm{P}_{t o t}$ at the outlets of wastewater treatment plants to $0.5 \mathrm{mg} \mathrm{l}^{-1}$. Moreover, a significant lowering of nutrient loading can be achieved as a result of the optimization of the use of mineral and organic fertilizers in agriculture. While these calculations can be further refined, they identify the main direction of action for a real and significant lowering of nutrient loading based on pressure indicators in the eastern Gulf of Finland of the Baltic Sea. 


\section{REFERENCES}

GOLUBEV D. A., SOROKIN N. D., GRIGOR'EV A. S., PEREDNIA T. V., 2009: Rezul'taty izucheniia kachestva vod v reke Neve v 2007-2009 gg. (Results of the study of water quality in the Neva River 2007-2009.) In Okhrana okruzhaiushchei sredy, pripodopol'zovanie i obespechenie ekologicheskoi bezopasnosti v Sankt-Peterburge v 2008 godu. (Environmental protection, natural resource use and environmental safety in St. Petersburg in 2008.) Eds. Golubev D. A., Sorokin N. D. Sezam, St. Petersburg.

HELSINKI COMMISSION, 2009: Eutrophication in the Baltic Sea: An integrated thematic assessment of the effects of nutrient enrichment in the Baltic Sea region. Baltic Sea Environment Proceedings, No. 115B, 1-148.

HELSINKI COMMISSION, 2007: HELCOM Baltic Sea Action Plan. Helsinki, Finland, pp. 1-103.

KONDRATYEV S. A., 2007: Formirovanie vneshney nagruzki na vodoemy: problemy modelirovaniia. (Formation of external loading on water bodies: problems of modeling.) Nauka, St. Petersburg.

KONDRATYEV S. A., BASOVA S. L., ERSHOVA A. A., EFREMOVA L. V., MARKOVA E. G., SHMAKOVA, M. V., 2009: Metod otsenki biogennoi nagruzki na vodnye ob'ekty severo-zapada Rossii. (A Method of Evaluation the Nutrient Loading on Water Bodies of Northwest Russia.)
Izvestiia Russkovo Geograficheskovo Obshchestva, (Proceedings of the Russian Geographical Society), 141, 2, 42-52.

KONDRATYEV S. A., MENDEL O., 1996: Mathematical Modelling of Runoff and Material Transport from Drainage Areas into Recipient Water Bodies. Hydrobiologia, 322, 237-240.

OECD, 1982: Eutrophication of Waters: Monitoring, Assessment and Control. OECD, Paris.

SAWYER C. N., 1947: Fertilization of lakes by agricultural and urban drainage. New England Water Works Assoc., 61, $109-127$.

TRUMBULL N., 2007: Pressures on Urban Water Resources in Russia: The Case of St. Petersburg. Eurasian Geography and Economics, 48, 495-506.

VODOKANAL, 2008: Godovoi otchet. (Yearly Report.) Vodokanal, St. Petersburg.

VOLLENWEIDER R. A., 1968: The scientific basis of lake eutrophication, with particular reference to phosphorus and nitrogen as eutrophication factors. Tech. Rep. DAS/DSI/68.27.

Received 15 August 2011 Accepted 13 March 2012 